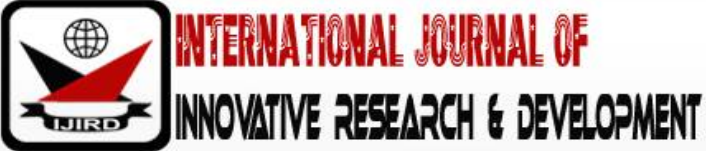

ISSN 2278-0211 (Online)

\section{Evaluation of Physicochemical Properties of Nano-Sized Hydroxyapatite Particles Synthesized from Cowbones}

\author{
Oa Babatunde \\ Professor, Department of Chemistry, Nigerian Defence Academy, Nigeria \\ I M Kangiwa \\ Ph.D. Student. Department of Chemistry, Nigerian Defence Academy, Nigeria \\ Md Faruruwa \\ Associate Professor, Department of Chemistry, Nigerian Defence Academy, Nigeria \\ P E Omale \\ Associate Professor, Department of Chemistry, Nigerian Defence Academy, Nigeria
}

\begin{abstract}
:
Pure and white Hydroxyapatite $\mathrm{Ca}_{10}\left(\mathrm{PO}_{4}\right)_{6}(\mathrm{OH})_{2}$ powder was synthesized from animal bone (Cowbone) using thermal decomposition method. The physicochemical properties of the synthesized hydroxyapatite were evaluated using $X$-ray diffraction analysis and Fourier Transform Infrared spectroscopy. The X-ray diffraction results revealed crystalline phase of hydroxyapatite while Scanning Electron Microscope analysis revealed the microscopic structure and nano size of the hydroxyapatite particle. Fourier Transform Infrared spectroscopy was used to identify functional groups in the material and did not indicate any organic components of the bone. Thermo gravimetric analysis confirmed the thermal stability of the hydroxyapatite. The in-vivo cytotoxicity test using Wistar Albino Rats did not indicate any toxic effects of the material at acute level. The research has not only shown economic potentiality of producing nano hydroxyapatite from this waste but offers a means of impacting positively on the environment.
\end{abstract}

Keywords: Thermal, synthesis, Albino Rats, Hydroxyapatite, microscope

\section{Introduction}

Hydroxyapatite $\mathrm{Ca}_{10}\left(\mathrm{PO}_{4}\right)_{6}(\mathrm{OH})_{2}(\mathrm{HA})$ is an inorganic component of natural bone and is very biocompatible and therefore used extensively in developing biomaterials(Bahrololoomet al, 2009). Synthetic hydroxyapatite is a popular bone replacement material because it has similar crystal structure to native bone apatite and this resemblance is the origin of the excellent biocompatability that HA exhibits with tissues enabling it to be incorporated into the body in the remodeling of the bone (Cox, 2014). In the last two decades, the use of bio-waste materials to produce HA powders using various synthetic techniques has been widely studied using such materials as eggshells, animal bone and cerals (Teerawat, 2015). The process of the preparation of HA form these materials is an interesting procedure where economic and environmental benefits are obtained through waste recovery, moreso, HA produced from biowastes such as animal bone may be less likely to be rejected by living organs due to physiochemical similarly to human bone (Sobczaket al., 2009; Ozawa and Suzuki, 2002). Several investigations have also been carried out to determine how critical properties of HA can be effectively controlled by varying the processing parameters taking into consideration of wide variety of methods for the preparation of Nano particles of hydroxyapatite (Shojal, 2013).The research aimed at synthesizing hydroxyapatite at nano level from this biowaste (cowbone) in order to contribute to the clinical demand of the material because hydroxyapatite in nano size has become a more preferred material as orthopedic and dental implants compared to hydroxyapatite in micro scale.

\section{Materials and Methods}

\subsection{Sample Collection and Preparation}

Cowbone (femur) samples were collected from two different abbatoirs, Kawo and Tudun Wada all within Kaduna metropolis, Nigeria and the bone samples collected were labeled K-Bone and KB-Bone respectively. The adhering meats on the Cowbone samples (femur; KB- BONE (403.25 g). K-BONE (451.65 g)) collected were first removed and scrapped mechanically using knife, then boiled separately in a cooker for $1 \mathrm{hr}$. $30 \mathrm{mins}$ to remove blood, remaining fat and adhering meat tissue (Mucaloet al., 2004). Cowbone samples was deproteinized externally by washing with $1 \mathrm{M} \mathrm{HCl}$ solution and finally followed with $1 \mathrm{M} \mathrm{NaOH}$ solution to ensure complete removal of any remaining proteins. The samples were then thoroughly washed with distilled water and dried in oven at $160{ }^{\circ} \mathrm{C}$ for 6 hrs., after which the bone samples were observed 
to have turned black with reduced weights of $288.0 \mathrm{~g}$ and $360.65 \mathrm{~g}$ for KB-BONE and K-BONE respectively. The dried bone was broken into pieces using hand grater and later ground using pestle and mortar into smaller particle size. The ground bones were later sieved to obtain particle size less than $450 \mu \mathrm{m}$ (KB-BONE $104.47 \mathrm{~g}$; K-BONE $124.8 \mathrm{~g}$ ) (Nasser et al., 2009).

\section{Synthesis of Hydroxyapatite Using Thermal Decompsoition Method}

\subsection{Synthesis of Nano Sized Hydroxyapatite from Cow Bone Samples (Soheilaet Al., 2017)}

The prepared samples of cowbone were used to synthesize nano sized hydroxyapatite using Thermal Decomposition method. Twenty grams $(20 \mathrm{~g})$ of the black bone powder was measured using analytical balance in four open aluminium crucibles each and then heated in furnace(furnace SXL, model no; 1006) at $900^{\circ} \mathrm{C}$ for 5 hours and was allowed to cooled inside the furnace overnight (Nasser et al., (2009) and Bahrololoomet al., 2009). The nano-sized hydroxyapatite was obtained after heating the black bone sample at $900^{\circ} \mathrm{C}$ for five hours as white solid powder. The white solid powder of nano hydroxyapatite was further ground using pestle and mortar into fine white powder

\section{Characterization of Synthesized Ha}

\subsection{Physical Characterization}

Conductivity was determined using conductivity meter, Jenway, England, with model No. DDS.307; refractive index was measured using Refractometer, Bellingam and Stanley England, with Model No. 909271 while the colour of the synthesized HA was determine using visual comparison

\subsection{In-Vivo Cytotoxicity Test}

Lorke's method of in-vivo cytotoxicity test was used to investigate the toxicity effects of the hydroxyapatite material usingninety (90) Wistar Albino Rats. In the first phase, different dose concentrations of $10 \mathrm{mg} / \mathrm{kg}, 100 \mathrm{mg} / \mathrm{kg}$, $1000 \mathrm{mg} / \mathrm{kg}$ of the synthesized HAwere administered while in the second phase $1600 \mathrm{mg} / \mathrm{kg}, 2900 \mathrm{mg} / \mathrm{kg}$ and 5000 $\mathrm{mg} / \mathrm{kg}$ of the synthesized HA material were also administered. The different concentrations were orally given to the Rats using syringe depending upon their respective weightsand were evaluated after 24 hrs. (Lorke,1983).

\subsection{Chemical Characterization}

Scanning Electron Microscope, phenomenon prox model, with model no. 4.5.3 was used to study the grain size and surface morphology of HA; Panalytical Empyrean Model X-ray diffractometer was used to determined size of the crystal particles, phase composition and degree of crystallinity; Thermogravimetricanalyser, Perkin Elmer TGA, with model No. 400) was used to evaluate the thermal stability and percentage weight loss of HA. Fourier Transform Infrared spectrophotometer, FTIR machine MB with model number 3000 was used to characterize the functional groups in the material and the spectra was acquired over a range of 400-4000 $\mathrm{cm}^{-1}$ The nano particle size was calculated using Scherrer's formula,

$$
\begin{aligned}
& \mathrm{D}=\frac{0.9 \lambda}{b \cos \theta} \\
& \text { Where } \\
& \lambda=0.154 \mathrm{~nm} \text { for } \mathrm{Cu} \\
& \mathrm{b}=\text { FWHM (Full width Half Maximum) } \\
& \theta=\text { Diffraction angle } \\
& \mathrm{D}=\text { particle size in nano meter }
\end{aligned}
$$

\section{Results and Discussion}

\subsection{Synthesis and Physical Characterization}

The results of synthesis and evaluation of physicochemical properties HA is presented in Table I.A total of eightyfour grams ( $84 \mathrm{~g}$ ) of the nano HA particles was synthesized from $160 \mathrm{~g}$ of powdered bone sample used representing about $53 \%$ yield. The colour of the HA synthesized is white which is in agreement with the report offeong (2012) on the colour of pure hydroxyapatite. The conductivity values range between $1.21-1.05$. while refractive index average value ranged between 1.668-1.657 these values observed agreed with those reported by Gittingset al., (2009). Hydroxyapatite in nano size derived from animal bone is considered economically viable because of availability and uncomplicated procedure. It was also observed from this study that some nano size hydroxyapatite synthesized from Bone-KCM could be classified asmesoporous materials (materials with pore sizes between 2-50nm) and these materials have recently been seen to be very promising in fields of separation science, optics, drug delivery and tissue engineering. In tissue engineering, mesoporous materials have also been shown to be attractive candidates as scaffold materials especially for bone regeneration, because high surface area scaffolds have been shown to enhance cell adhesion and cell proliferation 


\begin{tabular}{|c|c|c|c|c|c|}
\hline S/N & Bone Sample & $\begin{array}{c}\text { Quantity of } \\
\text { hydroxyapatite } \\
\text { Synthesized (g) }\end{array}$ & Colour & $\begin{array}{c}\text { Refractive } \\
\text { Index }\end{array}$ & $\begin{array}{c}\text { Conductivity } \\
\text { (ms/cm) }\end{array}$ \\
\hline 1 & K-BONE & 54 & White & 1.668 & 1.21 \\
2 & KB-BONE & 30 & White & 1.657 & 1.05 \\
\hline
\end{tabular}

Table 1: Results of Synthesis and Evaluation of Physicochemical Parameters of HA

\section{Chemical Characterization}

\subsection{SEM Analysis}

SEM images of nano hydroxyapatite synthesized from Cowbone (Fig1-2) showing that it contains a range of particles in agglomerates with spherical, hexagonal and irregular shapes and which conforms to the microstructure characteristic of nano particles. Bahrololoomet al., (2009) characterized hydroxyapatite from bovine bone ash and reported that its SEM images has spherical, hexagonal and irregular shapes which is consistent with the present study. The nanosize particles have the tendency to agglomerates thereby leaving pores in between them and because of this they are referred to as porous material which is beneficial as they would permit the circulation of body fluid throughout the coating when it is used as biomaterial implant (Huiet al., 2010). The SEM images also did not show any amorphous organic material which indicated that the organic component of the bone was eliminated after heating the bone at $400^{\circ} \mathrm{C}$. and a similar observation was reported by Holden et al., (2005).

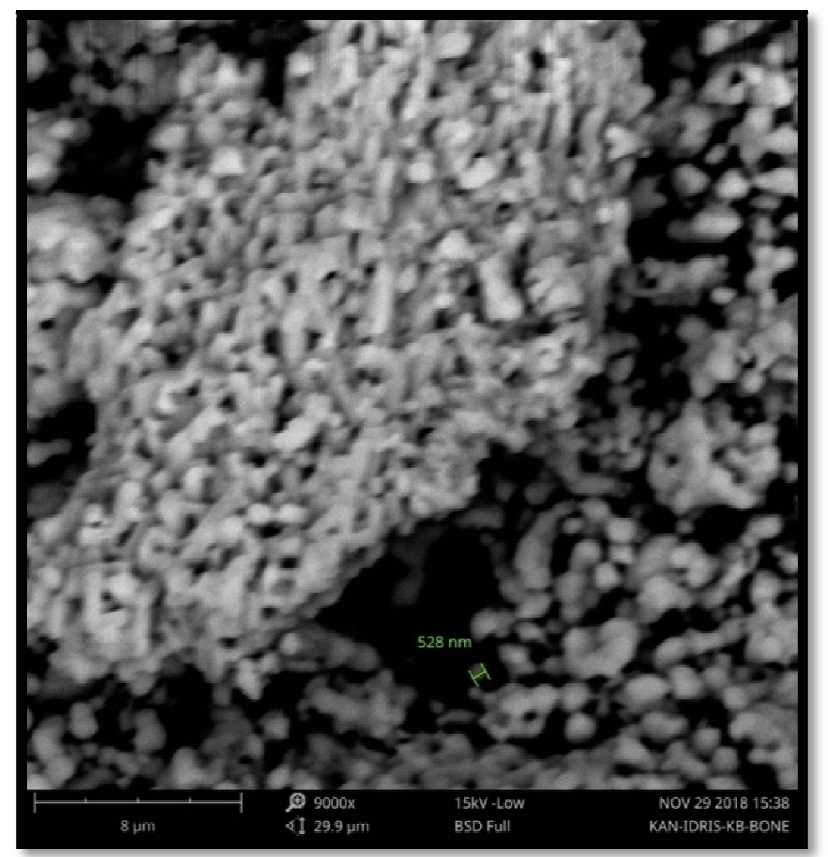

Figure 1: SEM Image for Hydroxyapatite Synthesized from Cowbone (KB-BONE) (9000x)

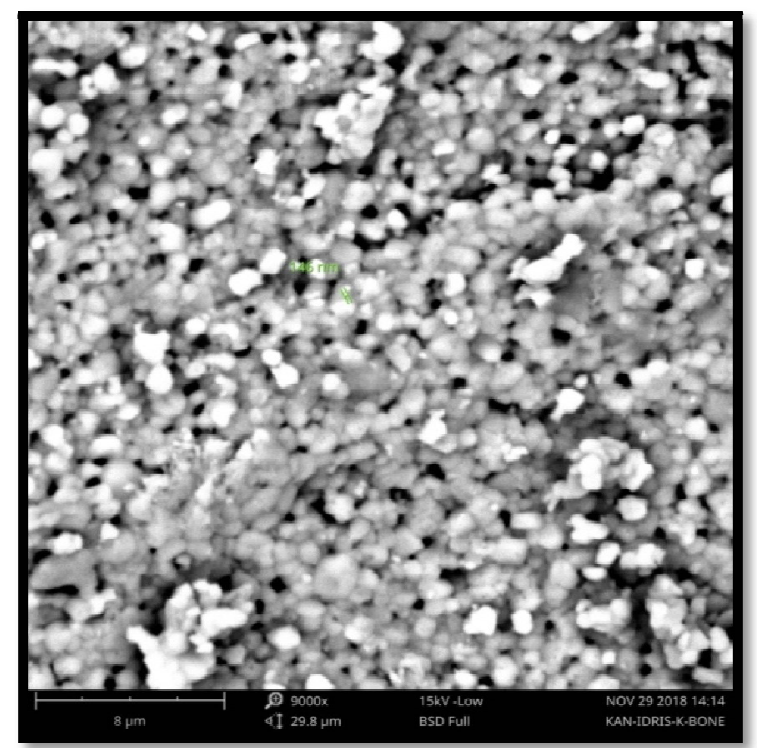

Figure 2: SEM Image for Hydroxyapatite Synthesized from Cowbone (K-BONE) (9000x) 


\subsection{FTIR Analysis}

The study FTIR spectra (Fig 3-4) for the synthesized HA from samples of Cowbonerevealed vibrations due to $\mathrm{OH}^{-}$ groups at $3857.8 \mathrm{~cm}^{-1}, 3570.5$ and $3738.5 \mathrm{~cm}^{-1}$ and these values are similar to those reported by Huiet al. (2010) who detected OH-groups in FTIR spectra at $3751.1 \mathrm{~cm}^{-1}$ and Nasser et al (2009) detected $\mathrm{OH}^{-}$peak with $\mathrm{O}-\mathrm{H}$ vibration at $3569 \mathrm{~cm}^{-1}$ while Bahrololoomet al., (2009) detected vibrations due to $\mathrm{OH}^{-}$at $3571.9 \mathrm{~cm}^{-1}$ and $34536 \mathrm{~cm}^{-1}$.

The vibrations at $875.9 \mathrm{~cm}^{-1}, 1412.7 \mathrm{~cm}^{-1}$ and $1457.4 \mathrm{~cm}^{-1}$ are corresponding to vibration mode due to $\mathrm{CO}_{3}{ }^{2-}$ ion and this agrees with Brahimet al., (2014) who observed $\mathrm{CO}_{3}{ }^{2-}$ at $876 \mathrm{~cm}^{-1}$ and $1456 \mathrm{~cm}^{-1}$ while Salma et al., (2010) detected absorption bands of $1482 \mathrm{~cm}^{-1}, 1424$ and $875 \mathrm{~cm}^{-1}$ ascribed to $\mathrm{CO}_{3}{ }^{2-}$ ion. The main characteristic broad bands of $\mathrm{PO}_{4}{ }^{2-}$ stretching were observed at $1021.3 \mathrm{~cm}^{-1}$ and $1088.4 \mathrm{~cm}^{-1}$.and the results is in agreement with Tanaka et al.,(2003) who detected characteristic peaks due to $\mathrm{PO}_{4}{ }^{2-}$ stretching vibrations at $1051 \mathrm{~cm}^{-1}$. The amide peaks representing the proteinous part of the bone usually at $1559 \mathrm{~cm}^{-1}$ and $1636 \mathrm{~cm}^{-1}$ were not seen in the FITR spectra. This confirmed the elimination of collagen after heating the bone samples above $400^{\circ} \mathrm{C}$.Figueiredoet al (2017) in the study of microstructure of hydroxyapatite derived from human and animal bone observed that all absorptions bands originated by collagen, precisely those at 1548 and $1634 \mathrm{~cm}^{-1}$ disappeared after calcination at $600^{\circ} \mathrm{C}$, which suggests that the organic component of the bone has been removed as observed in the study.

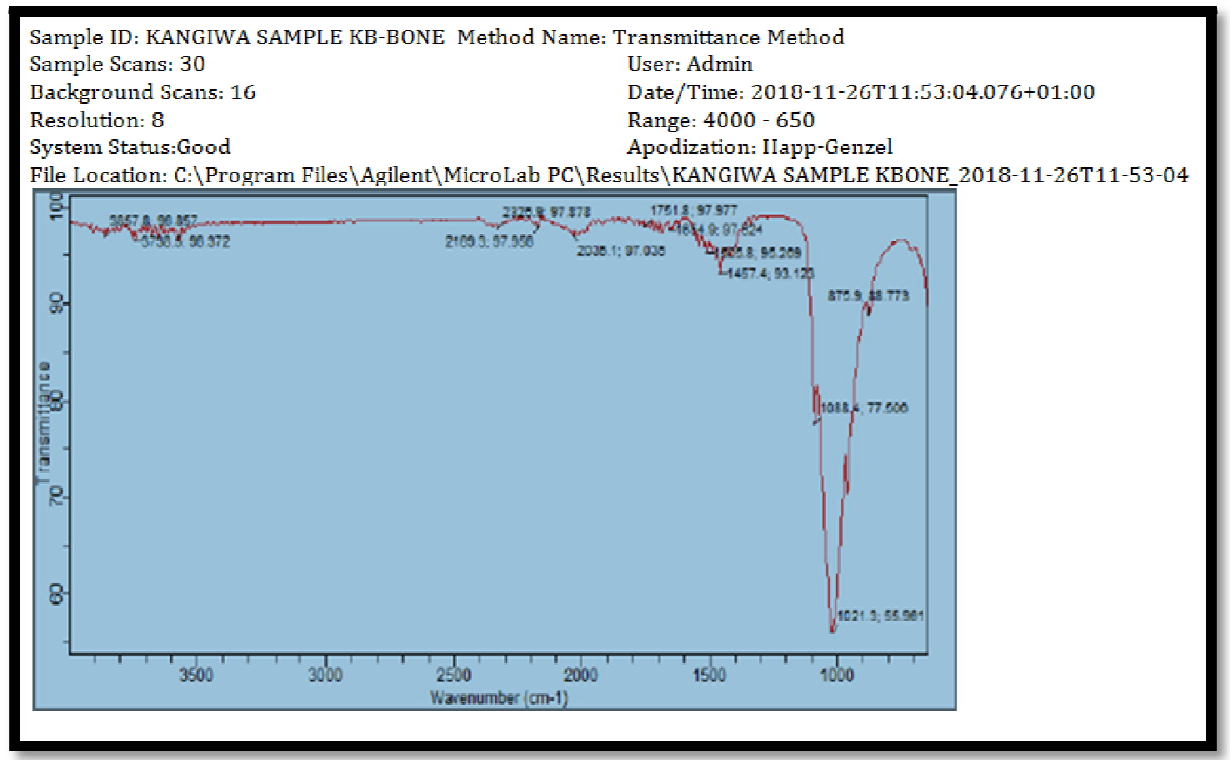

Figure 3: FTIR Result for Hydroxyapatite Synthesized from Cowbone (KB-BONE)
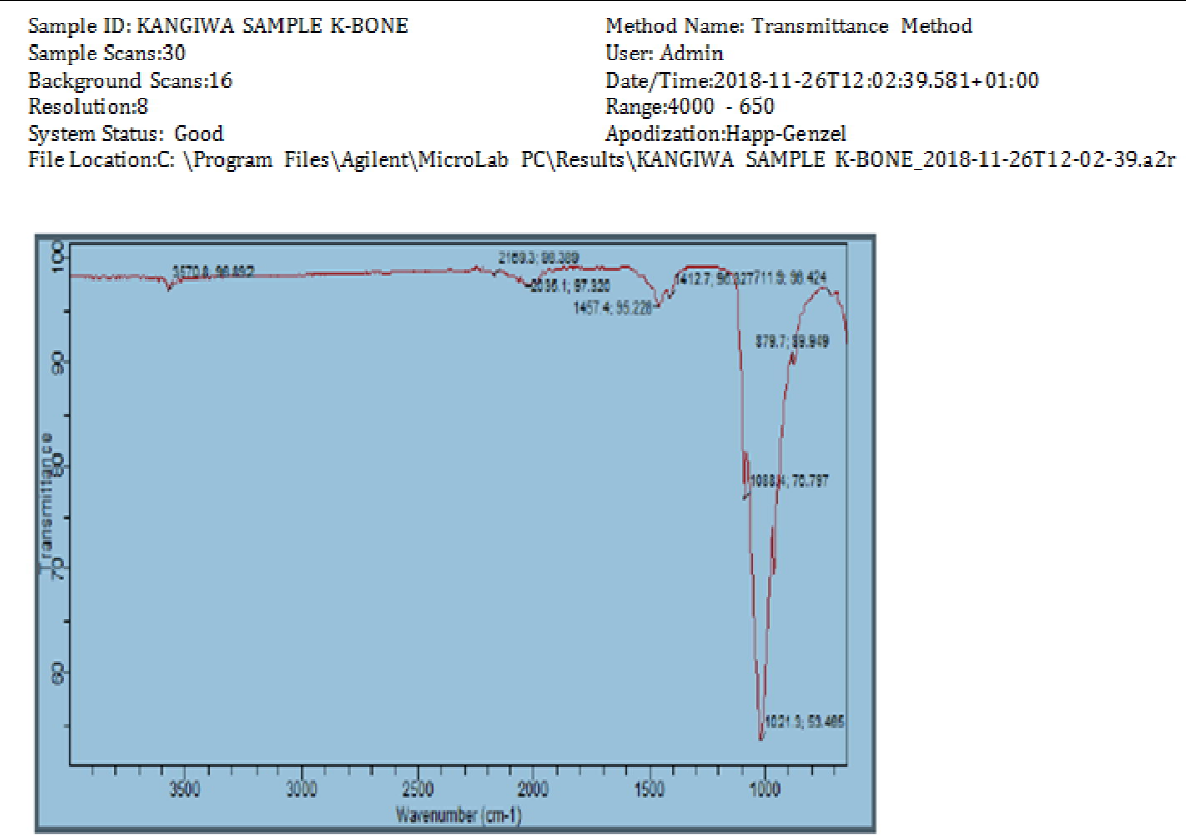

Figure 4: FTIR Result for Hydroxyapatite Synthesized from Cowbone (K-BONE)

\subsection{TGA Analysis}

The TGA analysis (Fig 7 and 8) shows that there was minor weight loss below $280{ }^{\circ} \mathrm{C}$ and major weight loss between $230-500{ }^{\circ} \mathrm{C}$ for the samples analyzed representing $6 \%$ minor weight loss and $74 \%$ major weight loss for HA 
synthesized from K-BONE and $6 \%$ minor weight loss and $81 \%$ major weight loss for KB-BONE. The minor weight loss observed was due to the surface, absorbed water and other volatile matter while major weight loss was attributed to the removal of organic components of the bone. The material was found to be thermally stable from $610{ }^{\circ} \mathrm{C}$ up to $900{ }^{\circ} \mathrm{C}$ as no significant weight loss was observed. This agreed with Masudet al., (2017) who reported a thermally stable hydroxyapatite beyond $650{ }^{\circ} \mathrm{C}$ from their TGA results.

\subsection{XRD Analysis}

The XRD peaks of nanoHA synthesized from cowbones were all observed(Fig 5 and 6) having narrow and sharp peaks and the width becoming narrower along the peak height and these are characteristics identification confirming both crystalline and major phase of the material which agreed with report of Sandeepet al., (2012). The XRD pattern was also marched with diffraction pattern by Joint Committee for Diffraction Pattern Standard (JCPDS card 00-009-432) which further confirmed major phase in this study as hydroxyapatite. The particle size of HA synthesized is presented in Table 2 which revealed the nano size of synthesized hydroxyapatite

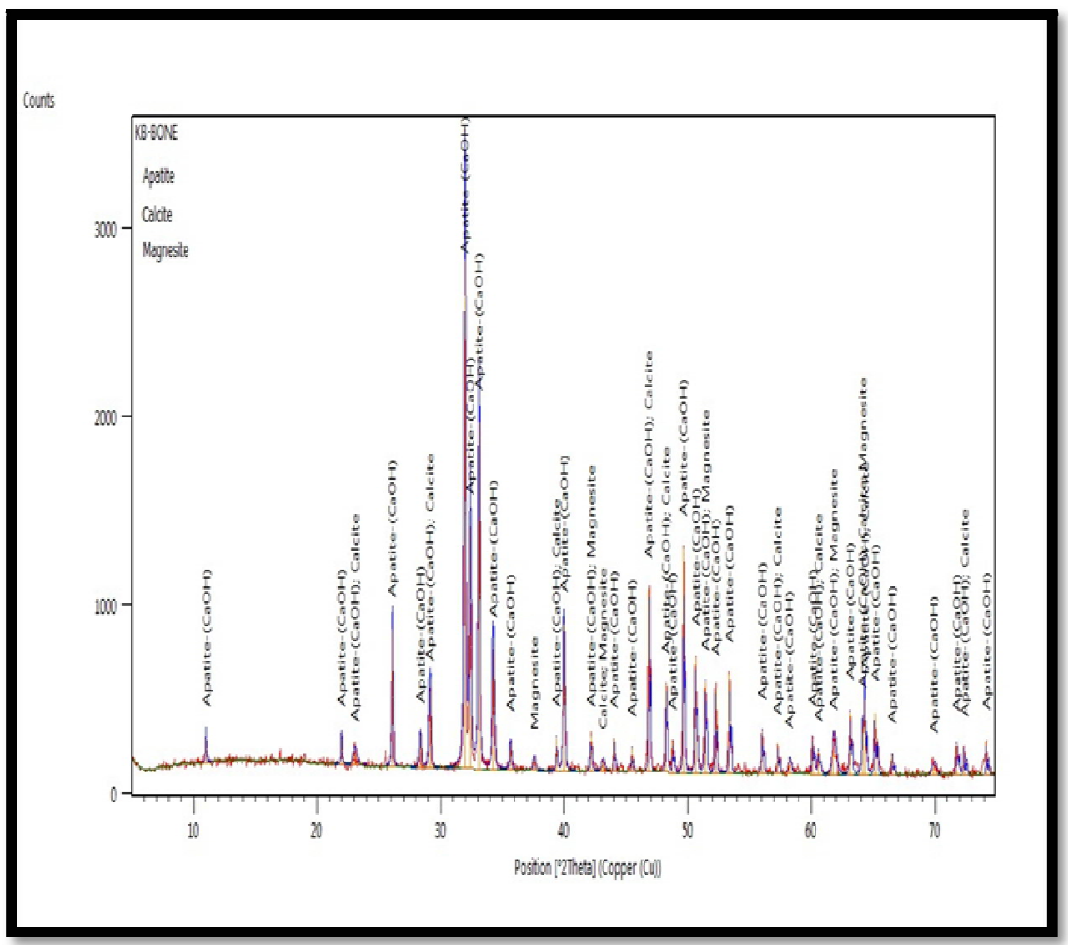

Figure 5: XRD Results for Hydroxyapatite Synthesized from Cowbone (KB-BONE)

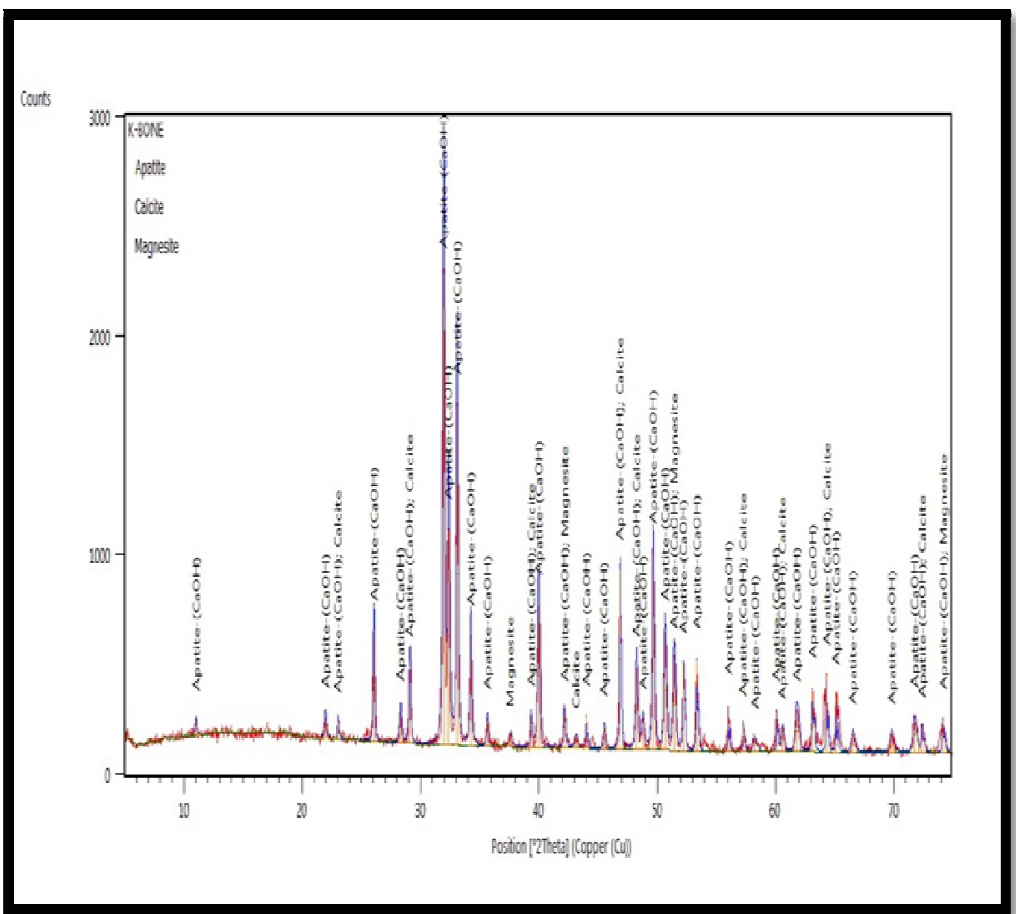

Figure 6: XRD Results for Hydroxyapatite Synthesized from Cowbone (K-BONE) 


\begin{tabular}{|c|c|c|c|c|}
\hline SAMPLE & $\begin{array}{l}\text { DIFFRACTION } \\
\text { DEGREE (2 } \theta)\end{array}$ & $\begin{array}{l}\text { B (FWHM) IN } \\
\text { DEGREE }\end{array}$ & $\begin{array}{l}B \quad(F W H M) \\
\text { Radian }\left(10^{-3}\right)\end{array}$ & $\begin{array}{l}\text { PARTICLE } \\
\text { IN nm }\end{array}$ \\
\hline KB-BONE & $\begin{array}{l}21.9624 \\
23.0620 \\
61.8119 \\
69.8954 \\
72.3802\end{array}$ & $\begin{array}{l}0.1023 \\
0.3070 \\
0.3070 \\
0.3070 \\
0.1023\end{array}$ & $\begin{array}{l}1.78 \\
5.36 \\
5.36 \\
5.36 \\
1.78\end{array}$ & $\begin{array}{l}79 \mathrm{~nm} \\
54 \mathrm{~nm} \\
50 \mathrm{~nm} \\
27 \mathrm{~nm} \\
79 \mathrm{~nm}\end{array}$ \\
\hline K-BONE & $\begin{array}{l}21.9612 \\
26.0593 \\
31.9387 \\
34.2320 \\
40.6401\end{array}$ & $\begin{array}{l}0.2047 \\
0.1279 \\
0.1791 \\
0.1791 \\
0.1791\end{array}$ & $\begin{array}{l}3.57 \\
2.23 \\
3.12 \\
3.12 \\
3.12\end{array}$ & $\begin{array}{l}39 \mathrm{~nm} \\
103 \mathrm{~nm} \\
52 \mathrm{~nm} \\
47 \mathrm{~nm} \\
65 \mathrm{~nm}\end{array}$ \\
\hline
\end{tabular}

Table 2: Particle Size for Nano-Sized Hydroxyapatite Obtained from Cowbone

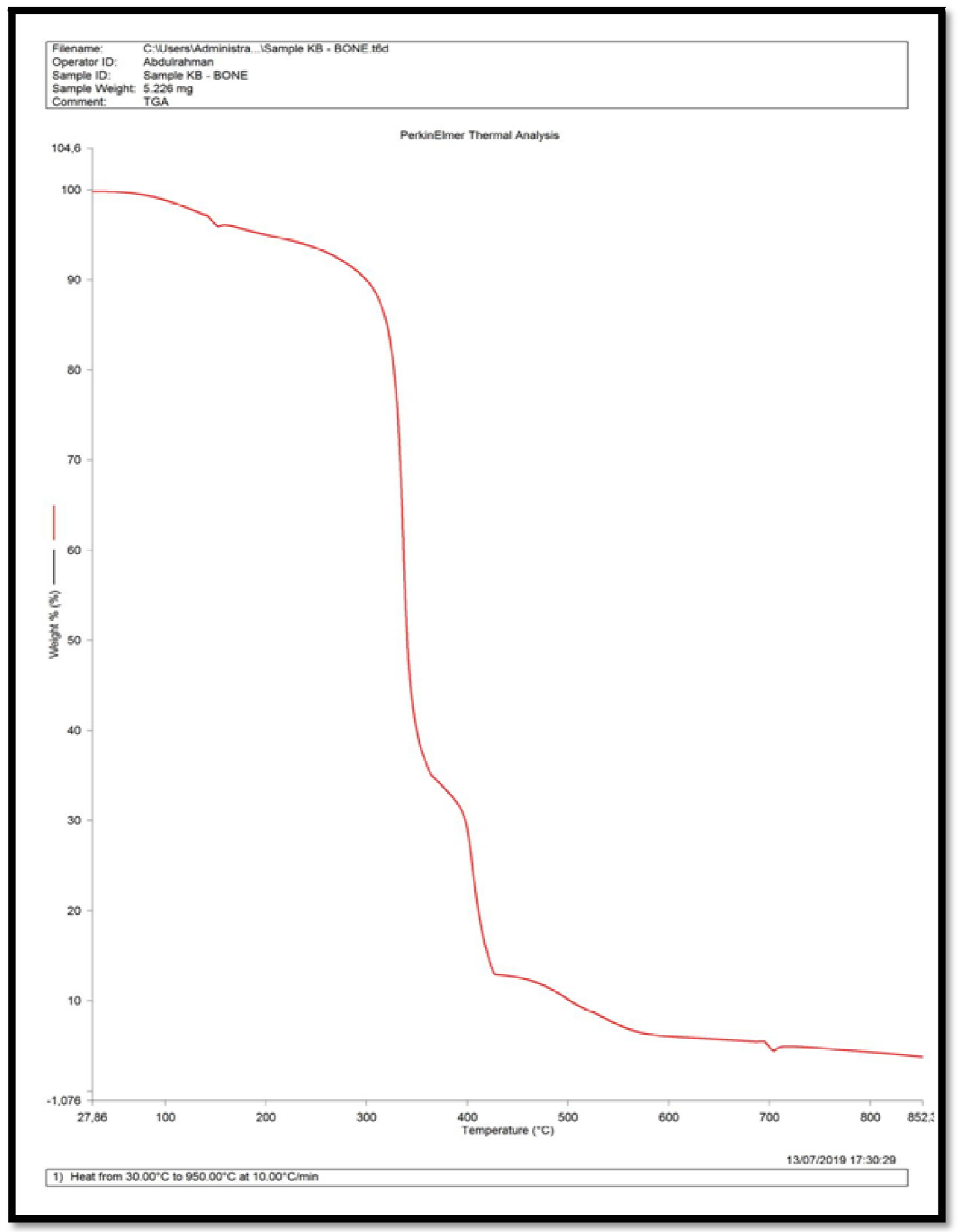

Figure 7: TGA Results for Hydroxyapatite Synthesized from Cowbone (KB-BONE) 


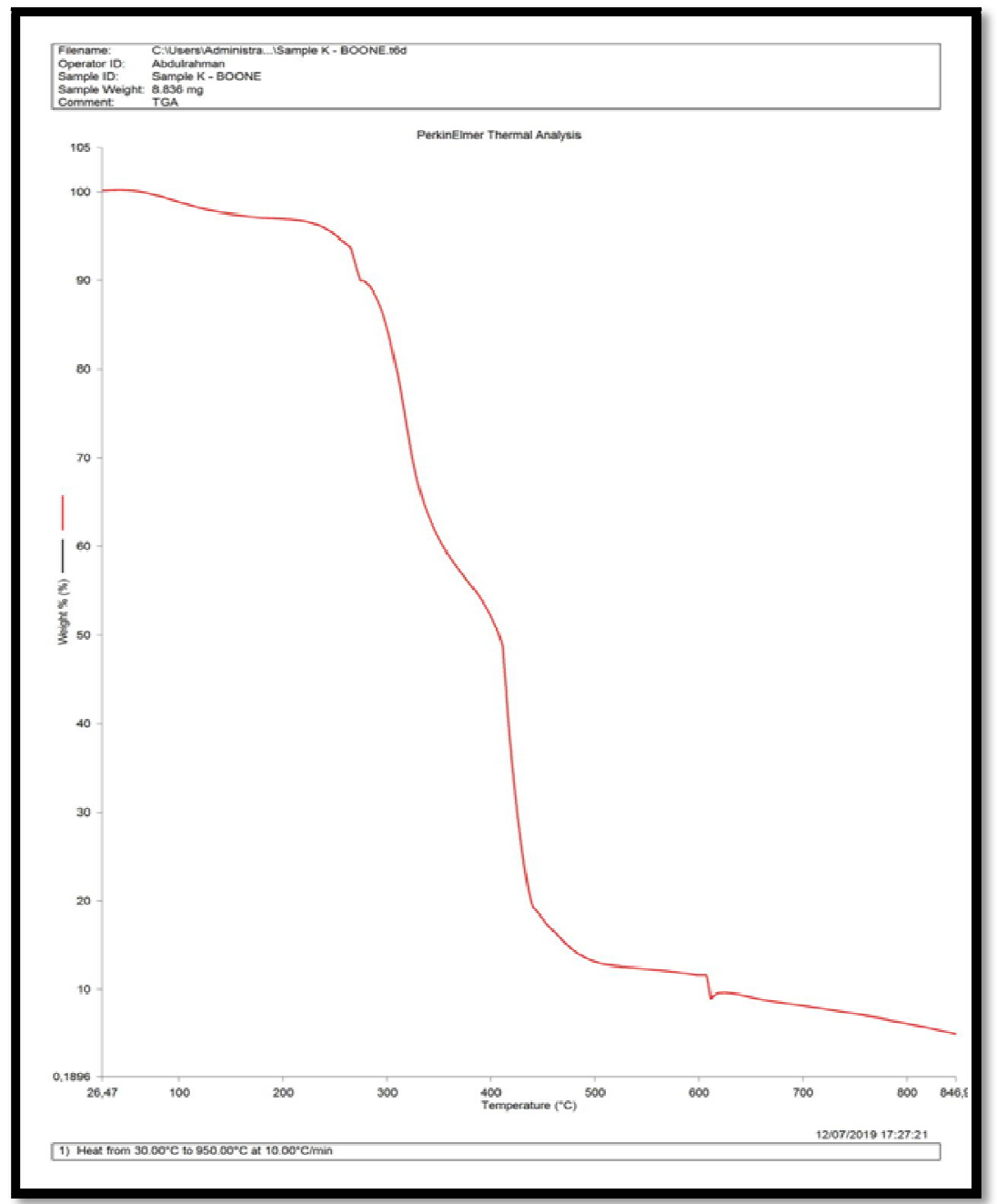

Figure 8: TGA Results for Hydroxyapatite Synthesized from Cowbone(K-BONE)

\subsection{In-vivo Cytotoxicity Test}

The results from in-vivo cytotoxicity test in both Phase 1 and phase 11 presented in Table 3 did not indicate any toxicity effects arising from different dose concentrations of the synthesized material administered orally to the Albino Rats after 24 hrs. evaluation. The results of the acute toxicity test in this study are similar to the results of chronic toxicity investigation of nano-HA using Wistar rats reported by Remiya and Mohanan (2017).

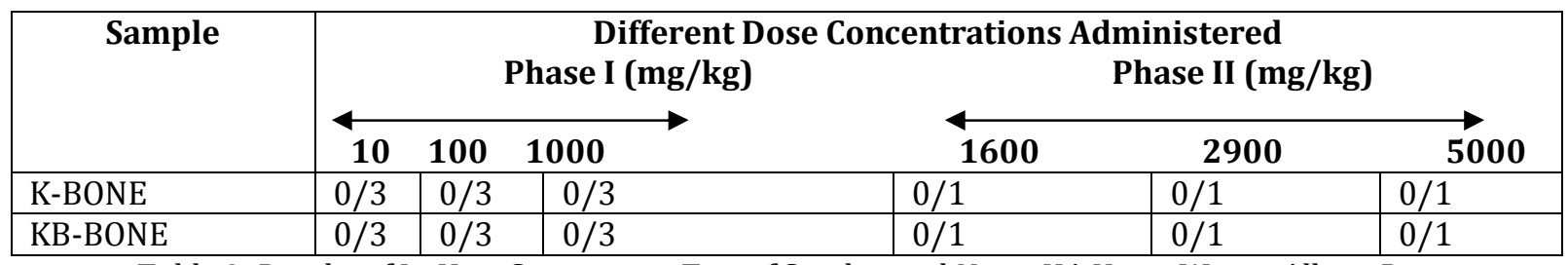

Table 3: Results of In-Vivo Cytotoxicity Test of Synthesized Nano-HA Using Wistar Albino Rats KEY: Numerator Is the Number of Deaths of Animal Recorded and Denominator Is the Number of Animals Used

\section{Conclusion}

Nano sized Hydroxyapatite (HA) powder was synthesized from cowbone samples using thermal decomposition method. The physical characterization indicates pure and white product in powdered form while in chemical characterization, FTIR and XRD indicated the product as having major phase as hydroxyapatite, crystalline and in nano size. SEM analysis revealed the nano grain size of the material in nano metric region while TGA indicated thermal stability of the material between $700{ }^{\circ} \mathrm{C}$ and $900{ }^{\circ} \mathrm{C}$. In-vivo cytotoxicity test using Wistar Albino Rats revealed no toxic effects of the material. The study showed the economic viability of using this natural source in producing HA material which will contribute in meeting the clinical demand of the HA for orthopedic applications in an environmentally friendly process.

\section{Acknowledgement}

This work was supported by Nigerian Tertiary Education Trust Fund (TetFUND) grant of 2017 


\section{References}

i. Bahrolololoom, M.E., Javidi, M. Javapour, S. and Ma J. (2009): Characterization of natural hydroxyapatite extracted from bovine cortical bone ash. Journalof Ceramic Processing Research. 10(2): 129-138.

ii. Brahim, C.I., Khalid, Y., Ahmed, Y. and Asmae, M. (2014): A Novel Method to synthesize nano crystalline hydroxyapatite: characterization with X-ray diffraction and infrared spectroscopy. Journal of Applied Chemistry. $7(3): 407-112$.

iii. $\quad$ COX S.C. (2014); Synthesis Methods of hydroxyapatite.Researchgate. 1: 1-9.

iv. Dan Nicole, U., Nicole, A., Rodica, M.F., Elena, U.S. and Cristiana, Z.R. (2016): Synthesis Method for Obtaining Hydroxyapatite Nano Powders by Chemical Precipitation. Journal of Recent Researches in Communication, Automation, Signal Processing, Nanotechnology, Astronomy and Nuclear Physics. 2:346-353.

v. Enamul Hogue M., Nurulk, S., Leng-Chuam, Y. and Ansari, M.N.M (2014): Synthesis and Characterization of Hydroxyapatite bioceramic. International Journal of Scientific Engineering and Technology. 3(5): 458462.binson

vi. Figueiredo M., Fernando A., Martins G. Freitas J, Judas F and Fiqueiredo M (2010): Effect of the calcinations temperature on the composition and microstructure of hydroxyapatite from human and animal bone, Journal of Ceramic International 36: 2383-2393

vii. Gittings, J.P, Bowen, C.R., Dent, A.C.E., Turner I.G., Baster F.R. and Chaudhuri, J.B. (2009).Electrical Characterisation of Hydroxyapatite-based bio-ceramics ActaBiometerialia 5: 7843-754.

viii. Holden, J.L., Phakey, P.P. and Clement, J.G. (2005): An X-ray Study of the Paracrystalline nature of bone apatite. Journal of Forensic Science International.74:29-45.

ix. Jeong, K.I. (2012): Experimental study of osteo-integration and stability of intentionally exposed hydroxyapatite coating implants'. Journal of the Korean Maxillofacial Reconstructive Surgery 34(1) 12-16.

x. Loo, S.C.J., Moore, T., Bank, B. and Alexis, F. (2010): Biomedical Application of hydroxyapatite Nano particles.Journal of Current Pharmaceutical Biotechnology (11) : 333-342

xi. $\quad$ Lorke D (1983): A new Approach to Practical Acute toxicity testing, Journal of Toxicology 54:275-287

xii. Masud R, Naznin A, Shaifur R, Hossen M.J. and Sikder MA (2017): Extraction of hydroxyapatite from bovine and human corticole bone by thermal decomposition and effect of Gamma Radiation: A comparative study, International Journal of Complementary \& alternative medicine 8(3): 263-272

xiii. Mucola, M.R., Foster, D.L., Wieggo, S. and Kirbu, J. (2004): The novel use of waster animal bone from New Zealand agricultural sources as a feed back for framing plasma sprayed hydroxyapatite coatings on biomedical implants materials. JABFM 2: 65-119

xiv. Nasser, A.M.B., Myung, S.K., Omran, A.M. Fahemem, A. S. and Hak, Y.K. (2009): Extraction of Pure Natural Hydroxyapatite from the bovine bones bio-wastes by three different methods. Journal of Materials Processing Technology.209: 3408-3415.

xv. Ozawa, M. and Suzuki, S. (2002): Micro structural development of natural hydroxyapatite originated from fish bone waste through heat treatment. Journal.American.Ceramics. Society.85(3), 1315-1317.

xvi. Remiya N.S and Mohanan R.V (2017); Investigation of chronic toxicity of hydroxyapatite nano particles administered orally for one year in Wistar rats, Journal of Materials Science and Engineering, Vol 76(1):518-527

xvii. Salma K., Liga, B.C. and Nataliya, B. (2010): Calcium phosphate bioceramics prepared from wet chemically precipitated powders, Journal of Processing and Applications of Ceramics. 4(1) 45-51,

xviii. Sandeep, S., Deepak, Mehta and Agarwal, R.D. (2012): Characterization and thermal analysis of hydroxyapatite bioceramic powder synthesized by sol-gel technique: International Journal of Advanced Science Research and Technology 2(3):281-282.

xix. Shojal, M.S. (2013); Synthesis Methods for Nano-sizedhydroxylapatite with diverse structures, ACTA Biomaterialia Vol. 9(8) pp. 7591-7621.

xx. Sobczak, A., Kida, A. Kawaski, Z. and Wzoreck, Z. (2009). Evaluation of the biomedical properties of hydroxyapatite obtained from bone waste. Polis Journal of Chemical Technology 11(1): 37-43.

xxi. Soheila, S.R., Omid, G., Ahmad, M and Mohammed, H.F. (2017): A comparative study of physicochemical properties of hydroxyapatite powders derived from natural and synthetic sources. Russian Journal of Nonferrous Metals.58 (3): 276-286.

xxii. Teerawat, L. (2015): Synthesis of hydroxyapatite from biogenic wastes, Engineering Journal 42(3): 269-275. 